Article

\title{
Contemporary Religious Changes in the U.S.: Responses to the Fracturing of Religious Life
}

\author{
Verna Marina Ehret \\ Department of Religious Studies, Mercyhurst University, Erie, PA 16546, USA; vehret@mercyhurst.edu
}

Received: 18 March 2019; Accepted: 23 April 2019; Published: 28 April 2019

\begin{abstract}
The purpose of this essay is to explore the changing religious landscape of the United States in relation to social and political changes and how scholars of religion ought to respond to those changes. These changes are being evaluated through recent developments in theological narratives of the last 15 years in light of the data provided by the Pew Forum's Religious Landscape Survey from 2007 and 2014. Special attention is paid to the impact of the 2016 election on social and political narratives and their impact on religious life and religious narratives. The essay argues that scholars of religion have an important voice in this changing landscape to provide tools for building community in diversity and challenging narratives of exclusion that seek to dominate the religious landscape of the United States.
\end{abstract}

Keywords: religious landscape; immigration; United States; Narrative Theology

\section{Introduction}

I teach Religious Studies in a small regional college in the North Eastern part of the United States. I have a very inquisitive student whose basic questions in almost every Religious Studies class are a variation on either "How do these theological or ideological shifts affect the people in the congregations?" or "Can we tell religious people they are wrong if what they are saying seems dangerous?" The questions always give me pause. What does the academy have to do with the people in the pews? What does the academy, if its goal is careful and thoughtful study and development of religious traditions, have to say about the way religion is taught and practiced in churches and homes? As a scholar of religion, a teacher, and a constructive theologian, this question the student raises has highlighted for me the importance of public scholarship to continually reshape the narratives of religion that guide personal, public, and political life in the United States. The question from the student reflects the questions of the American people that paraphrase Tertullian, "What does the academy have to do with the realities of human experience and religious life?" The goal of this essay is to move the scholar of religion beyond the classroom into the public domain in order to enhance the religious literacy of the general population of the United States and to respond to the theological and moral crises we face with the fracturing of religion as it changes in the contemporary world. As a constructive theologian by training, my approach to this move into the public domain is to find ways to continually revise and enhance the narratives of religion, given the ever changing religious landscape of the U.S.

Addressing those changes requires recognition of the interconnection of religion, politics, and social life. While as a constructive theologian I am wary of reductionist views of religion that want to limit religion to its social or political functions, religion's connections to these aspects of personal and public life cannot be ignored. The challenge, then, is to construct religious narratives in such a way that they invite community and belonging rather than create factions and fractionalizing of the American experience. The fractionalizing of attitudes about how one is a "true American" creates not only tremendous anxiety but also real harm to real people, the very people to whom religious communities 
globally claim to reach out. Religion in the United States is intimately tied to political and public life. Whether changes in religion are caused by certain political elements or political issues are driven by religion is difficult to tell. The United States is a secular nation, but it is also a deeply religious one. As William Cavanaugh has said in discussions of religion and violence, the secular-religious divide is a false dichotomy (Cavanaugh 2007). While the U.S. constitution guarantees in the first amendment both the freedom from religion (that there will be no established religion) and the freedom for religion (that one is guaranteed the free exercise of religion), it does not guarantee that religion has no place at all in public life. There is no formal religious test to hold public office, but that does not mean people do not use the perceived religion of candidates to determine whether or not they are worthy of public office. For example, people were concerned that John F. Kennedy would be more beholden to Rome than to the American people. Barak Obama was "accused" by many of being Muslim, an idea that in their eyes made him unfit to hold office. Representative Ilhan Omar, (Democrat from Minnesota) who wears a hijab, has become a lightning rod for anti-Islamic rhetoric in political and public domains (Rosenberg 2019). The contemporary changes in religion in the United States today are tied inextricably to changing demographics (immigration, refugees, and LGBTQIA persons) and politics, and the narratives used to frame specific events into either a crisis or an opportunity.

If the question of this essay is how religion is changing in the United States, the answer may be that religion in the United States today can be seen as fractured, perhaps even broken and in need of the religious literacy scholars can provide. Religion is changing organically with cultural shifts, inorganically with intentional narratives about these shifts, and confrontationally as the narrative shifts become attacks on individuals and communities outside one's narrative community. So the purpose of this essay is not only to look at the way the intermingling of religion with social and political life is changing religion, but also how scholars of religion might respond to some of these changes that can threaten the ability of the United States to function as a democratic collective that is made stronger rather than weaker by its diversity. As Lester Kurtz put it in his study of globalization and religion, "Sociologists should use their analytical tools to assess the role of religion in the global community and become involved in the lively debates about the future of humanity that will ensue" (Kurtz 2015). Scholars of religion, it may be argued, have a responsibility to guide community responses to the plurality of religious perspectives in the United States. These responses need to allow for constructive engagement with diversity, to protect the integrity of life, and to promote human flourishing rather than having religion be used as a weapon for the destruction of the "other."

\section{Narrative Construction and Performative Narratives of Reconciliation}

Constructive theology as I engage it is the continual reconstruction of religious narratives to meet the needs of an ever changing society. Narrative identity, as developed through the work of Paul Ricoeur (Ricoeur 1995), explains human engagement with the world through the process of story-telling. One lives not just as a series of events, but as a protagonist in the world that engages the stories of others. One's story exists within a network of stories: family, community, nation, humanity, and cosmic or religious narratives. While in one sense these narratives are concentric circles, in another sense they are an ever evolving complex of narrative threads in which one lives. Beginning with individual narrative identity, one finds oneself always in the process of writing one's story. But I construct my narrative in the tension between what is true and what I want to be true. I may add or subtract or otherwise alter my story in order to project to the world what I want others to see. My intentional narrative construction may direct, but is not fully in control of my whole narrative. Much of my narrative is impressed upon me externally, and my little narrative exists within a larger collective. In some sense, our encounters and interactions with others always have a narrative structure as we become plot points in each other's stories and reflexively absorb elements of the other's story into our own. 
Communal identity is a part of individual identity. However, as Presser points out, the narrative of the other creates both connection and distance (Presser 2016). If I cannot somehow connect their story to my own, I cannot see them as a part of my community. Connection requires imagination. Elsewhere I have described this connection as a transcontextual narrative (Ehret 2014). This type of narrative is an alternative to the little narratives that divide us and the meta-narratives that invite some while excluding others. The goal of the transcontextual narrative is to build bridges between the narrative threads where my world view finds something familiar in yours. A frame is created in which we can co-exist not only despite some differences, but more importantly together with those differences. This engagement of a transcontextual narrative that speaks within the language of particular communities but also reaches beyond them is, I would argue, at the heart of the "American Values Religious Voices" project that developed in January of 2016. This project engaged what might be called "The American Narrative" in ways that creates connections across diverse perspectives to create reconciliation and belonging, a sense of being at home in the diversity of our narrative identities and threads.

Social and political narrative identity is the frame through which the individual lives and communities act. Whether or not I can connect another's story to my own, they are connected in that we are collectively apart of the larger society. The I and the you are integrated in a we whether I want them to be or not (Klemm and Schweiker 2008). Facing a shockingly divided population, it will require significant imagination to connect the individual stories into a whole that reconciles that distance. This is accomplished, I argue, through the performative quality of narrative. If I expand my thinking out far enough, my narrative intersects with every other narrative. Social, political, and theological change can be constructed and directed in ways that negate the other and in ways that affirm otherness. Narrative can create reality.

Performative narrative is narrative that acts. For example, in a marriage ceremony the officiant declares the pair to be married and it is so. But of course it is not that simple. Two children playing at marriage cannot have a third friend declare them married and it be so. Performative language requires one to have the authority to speak. That authority is socially recognized, and without that authority the language is not performative. Recognition is a key aspect of performative narrative (Stumm 2014). One has to be recognized as someone who has the authority to make something happen by speaking. This is usually done by some kind of ceremony recognized within the social narrative as endowing the individual with the authority to shape the community through speech. In addition to authority and recognition, however, is also the context in which words are expressed. A minister at a party can jokingly "marry" two people, but that does not make them married. The context in which the words are spoken must also be agreed upon to be one in which the words become performative. So a president speaking not as a private citizen but as a president can say things that cause action because of the context and the nature of the office.

The context in which language becomes performative can also change if the person speaking has a recognized authority to reshape the context. The President of the United States cannot shape policy by Twitter, or can they? Through his zealous use of Twitter, President Trump has reshaped the context in which presidential speech becomes performative. While Twitter cannot replace more commonly accepted contexts, it has been drawn into the domain of performative speech. In reading the tweets of the President, one sees him connect to the national narrative by shaping his description of that narrative to fit his own identity. His reactions to the world become the national identity, the "who we are" of patriotism. While it would be false to say that the rise in hate crimes and public hate speech is simply caused by Trump, his speech actively brings into being an environment that legitimizes these sub-narratives that have always been present. They no longer need to hide. They are welcome in public discourse as "free speech." It is protected speech, and the assumption by the defenders of hate speech is that protected speech and moral speech are the same thing. The result has been that protesting these acts of free speech has become unprotected speech and a violation of "who we are," as seen in the student protests at Columbia (Roll 2017). The national narrative has shifted to bring into 
the light what has been repressed. In creating this environment of division, Presidential tweets become a performative narrative of exclusion that is reflected in religious narratives and the context in which reconciliation is needed. The rise in hate crimes tracked by organizations like the Southern Poverty Law Center and The Anti-Defamation League have shown a significant spike in the last two years, and often the perpetrators of hate speech or hate crimes invoke President Trump's voice as one that has raised the profile and acceptability of such language and acts of exclusion.

One can look at the specific example of U.S. Representative Ilhan Omar. President Trump has recently made tweets about her that actively call into question her loyalty (Itkowitz and Wagner 2019). Other leaders within the Republican Party have done the same because of comments she made about the impact of 11 September 2001 on American Muslims. While her comments can be read in multiple ways, it would appear her concern was with the way all Muslims have been held responsible for the actions of some. The speech becomes performative, creating a reality for their supporters where she represents the enemy, and the result has been a significant increase in death threats against her. But performative speech need not only fracture and exclude. As will be shown in a moment, the American Values Religious Voices Project will tap into the religious rhetoric of narratives of exclusion to see underneath them. The larger narratives of inclusion that underlie exclusionary narratives reflect the growing narratives of religious communities today as reconciliatory, inclusionary, and even pluralist. By drawing on the narratives of inclusion and more importantly pluralism (the active engagement with and embracing of difference), one can see the attempts at performative narratives that switch from exclusion to reconciliation. Reconciliation in this context is designed to bring people together in their diversity rather than exclude them because of it.

Given this description of performative narrative, a performative narrative of reconciliation and inclusion is one that can cross boundaries, build bridges, and reconstruct the community as a whole community. A narrative of reconciliation fosters the common good by making room for the previously marginalized and reconciling those who are estranged. As performative narrative, the social narrative actively creates community. As an example of this process one can look at the American Values Religious Voices project (American Values Religious Voices 2017). A group of scholars of religion created this project where 100 religion scholars were asked to each write a letter, and one letter a day would be delivered to President Trump, Vice President Pence, select members of the cabinet, and members of the 115th congress for the first 100 days of Trump's presidency.

The goal of the project was to highlight certain components of what might be called the American Narrative Identity as an attempt to redirect the national narrative away from the destructive narratives that were rising to the surface. Each letter attempts to turn national narratives toward ones that embrace our diversity and the growing religious diversity that is the American religious landscape. According to the organizers,

Words and actions during and after the election seemed to call into question fundamental values that have long defined our nation ... at this time of transition many people appeared to long for guidance, inspiration, and a reaffirmation of what it means to be an American.

Those observations sparked the idea that at this particular moment in our nation's history, our elected officials and our fellow citizens might welcome the insights of scholars of religious texts and teachings, individuals with an important voice to contribute to our national discourse (Values and Voices 2017).

The goal of the project was a redirecting of the national narrative to better reflect what the writers understand to be the American identity. Expressing one's own identity by inserting one's narrative into the national discourse creates space for recognition and belonging of the marginalized. But what does one do when the marginalized are not only the immigrants, the non-Christians, the non-white among us, but also those who feel deeply marginalized by the very multiculturalism that seeks to make space for these others? 
A performative narrative of reconciliation and inclusion rejects the narratives of exclusion and brings together all members of American society in this multi-religious landscape. It addresses the fracturing of religion not by making a single religious voice but by building community in the diversity. And here lies the problem. Can reconciliation happen if it requires a fundamental shift in someone's narrative identity? Perhaps reconciliation is not so much a bringing of all voices together but rather a choosing of a way of seeing humanity as an integrated we, rather than simply an I and a you. Reconciliation, then, is a transformational narrative to encourage people to abandon a narrative of exclusion in order to build this we.

That would seem to be precisely the nature of the narrative of reconciliation and inclusion that unfolds in these letters. The letter writers are predominately Christian or Christian leaning from a wide variety of denominations. But there are also a significant number of letters from Jewish and Muslim authors and then a small number of letters from Buddhists, Hindus, Sikhs, and one Native American. The writers come from a variety of ethnic backgrounds and sexual orientations. They are immigrants, teachers, community leaders, lay leaders, ministers, nuns, rabbis, and non-profit presidents. They work in biblical studies, theology, comparative study, history, law, ethics, Islamic, Hindu, Buddhist, Sikh, and Jain studies. In our criteria for performative narrative, these letter writers have both recognized authority for talking about national identity, values, and narrative through a religious lens and the context to support their authority as they speak. Their concerns are centered around immigration, inclusivity based on gender, gender identity, sexual orientation, race and ethnicity, and environmental protection. They spoke from the union of academic discipline and personal identity as a part of the national identity. They spoke to the religious underpinnings of the narratives of the United States and the ways that narrative has made space for care of the stranger in our midst. Themes of love and inclusion dominate much of the writing alongside the particularly interesting writing of Hebrew Bible scholars, who were more likely to highlight not only the texts that require care for the stranger but also those that were critical of governments that ignore their obligations to their people.

In particular, one can look to the letter by Beatrice Lawrence whose letter speaks to the deep structures of the "Judeo-Christian Tradition" of the United States that still dominates much of our national rhetoric. Looking specifically at Leviticus, Lawrence identifies the language that is so often repeated in churches, synagogues, and temples throughout the United States about the obligation to others. Her language is not foreign or outside. It is insider language seeking to expand the frame of inclusion that has been so severely restricted in contemporary social and political rhetoric. She says,

The book of Leviticus takes this notion of Israel's identification with the stranger even further. In the laws of the Jubilee, we read that once every fifty years, all land must be returned to its original owners ... God explains why: "For the land is mine; you are but strangers and sojourners with me" (Leviticus 25:23). The land is not ours; we are but temporary residents on this earth—strangers and sojourners each and every one of us.

The language of scripture fills contemporary discussions of belonging and exclusion. The idea of protecting a way of life that is distinctively American contains within it this notion of a Christian nation. While Lawrence is Jewish and speaking from a Jewish text, this language of Leviticus would be sacred text even to those seeking a Christian exclusive nation (Schleifer 2017). By reaching narratives of exclusion in their own language, transcontextual narratives can be built that reframe the way religious, political, national, and personal identity narratives are read and employed from exclusion to reconciliation.

Most interesting, however, was the unity of the voices. Even as the tone and topic changed from one letter to another, one could read it as a single voice. That might be the most striking thing about it. These were not, it should be pointed out, all people from traditionally liberal or progressive leaning institutions. While there was certainly a great deal of that, there were also voices from traditionally conservative schools. Despite this, the letters read as if it were one person speaking. Looking at the themes, two others stand out as particularly representative. 
- Uriah Kim (Kim 2017) writes, “Like my mother, I also believed in the American Dream; but I had my doubt as to whether I would ever be accepted and perceived as an American rather than as a perpetual stranger. It was during such a time of doubt in my youth when President Ronald Reagan shared a letter he received before he left office: "You can go to live in France, but you can't become a Frenchman. You can go to live in Germany or Italy, but you can't become a German, an Italian. He went through Turkey, Greece, Japan and other countries. But he said anyone, from any corner of the world, can come to live in the United States and become an American." You can imagine how relieved and happy I was to know that the President of the United States agreed with the idea that the United States is where foreigners not only can be welcomed but also can become Americans" (Values and Voices 2017).

Here is a moment of presidential performative narrative of inclusion. It is tied to a Republican President with whom so many exclusive narratives resonate, and yet the moment created inclusion and reconciliation. A bridge was built.

- Judith Plaskow (Plaskow 2017) writes, “What would it mean for each of us-especially those charged with formulating immigration policy-to call to mind our own experiences of migration, or those of our families, and to empathize with a new generation of migrants and refugees trying to reach these shores? How might we use the memories of our families' stories to create the welcome we wish our forebears had encountered? Instead of slamming the door on Syrian refugees and people from certain Muslim-majority nations, how can we use our own histories to forge a new relationship with the strangers among us" (Values and Voices 2017)?

The letters engage the language of academia intermixed the "American Narrative." They seek to connect yet critique, always respectfully, but often forcefully and with clear disapproval of the impact of both Trump's language and policies. These letters are performative. They bring about a world through the narrative, one they themselves inhabit. But are they performative narratives of reconciliation and inclusion outside the world of the writers? On the one hand, no. The intended audience likely never read the letters. And reading through Trump's tweets of the following two years indicates there was no impact at all at that level. In many ways, things are worse.

But these letters were not designed for the narrow world of academia or the federal government alone. There is a power and authority assigned to the letters by the very act of sending them to the highest authorities in the nation. They are designed to speak to the broad, diverse, and ever-changing world of religion in the United States. The letters have since been turned into a book, easily available through the group website and on Amazon. The books is titled, American Values Religious Voices: 100 Days. 100 Letters edited by Andrea Weiss and Lisa Weinberger. It contains not only the letters but also essays on the creation and impact of the campaign. The website of the group offers links to news articles and groups who have used it as a part of religious study. I personally have used the work of this group in teaching adult religious education classes at local churches in order to slowly spread the narratives of these letters. The group has made extensive use of social media in order to make the letters widely available as they were being written as well. The narrative of reconciliation can become performative when it (a) comes from sources of authority people feel they can trust, (b) speaks in the language of these communities in ways that allow for discussion and re-engagement with religious narratives, and (c) is made available in forms people will encounter it. Social media has become an essential part of that narrative reframing.

But one might ask why all of this work is necessary. The answer is the religious landscape of the United States is continually changing. As social and political realities change religious narratives must be able to respond to those changes or risk irrelevance. It is necessary for theology to be constructive. Theology must reconstruct itself in light of new social and political realities in order to speak to the needs of the whole people and the common good. I will therefore provide a brief look at the changing landscape of religion in America to more fully grasp the realities to which the American Values Religious Voices project and others are seeking to respond. 


\section{Changing Religion in the United States}

Religious life in the United States is fractured and fracturing around social, political, and theological issues. Among these issues are religious diversity, immigration, the rights of the LGBTQIA community, and the relationship of Christianity to U.S. political life and the world's religions that are also American religions. There are a variety of conflicting concerns expressed in these issues. Religion in the United States today is a tense topic of discussion fraught with dangers. These perspectives arise out of the narrative frames in which these issues are presented, interpreted, and lived. But analysis of the narratives first requires some understanding of the American context.

The Pew Forum on Religion and Public Life has been collecting and analyzing data on religion in the United States in order to track changes. In 2007 they ran the Religious Landscape Survey, conducted through phone interviews with people across the country. The data were compiled and analyzed and then the survey was run again in 2014 (Pew Forum 2014). What they learned through comparing the 2007 data with the 2014 data is not surprising. Religion in the United States is going through significant changes that can be connected to social, political, and theological shifts. As of 2014, 70.6\% of Americans considered themselves to be some form of Christian. 5.9\% of Americans identified as members of a non-Christian religion, $1.5 \%$ of Americans identified as "other religion," and $22.8 \%$ identified as religiously unaffiliated, which includes the religious Nones, atheists, agnostics, and people who just don't know.

Comparing the 2007 and 2014 data, some interesting trends reveal themselves regarding religious shifts in the United States. The analysis of the study shows overall a decline in the percentage of the American population that identifies as Christian and growth in those who do not identify with any organized religion (Nones). While some Nones are atheist or agnostic, many simply do not identify with any specific tradition. The shift, according to the Pew study, is happening across age (adults only, but in different age brackets), ethnic, and educational markers. In 2007 78.4\% of U.S. adults identified as Christian while in 2014 that number had gone down to $70.6 \%$. In $200716.1 \%$ of the U.S. population was unaffiliated while by 2014 that number was up to $22.8 \%$. And while in $20074.7 \%$ of the U.S. adult population identified as members of non-Christian religions, by 2015 that number had risen to $5.9 \%$. While most of the decline in Christian affiliation among U.S. adults has been seen in Catholic and Mainline Protestants, there has also been decline in the overall percentage of U.S. adults identifying as Evangelical Protestant. However, according to the Pew study, while there is a decline in the overall percent of the U.S. adult population identifying as Christian, there is growth in the ethnic diversity of these traditions, particularly in Hispanic/Latinx participation across the diverse forms of U.S. Christianity (America's Changing Religious Landscape 2015). This growth in ethnic diversity as well as the growth in non-Christian religions is in part due to immigration. Immigration is inseparable from religious life in the U.S., which means understanding the social, political, and theological shifts in religious communities is tied to the narratives about immigration. This is one of the primary places one can see the fracturing of religion in the United States, an issue we will return to in a moment.

It is important to note that, according to the Pew study, while the percentage of the population identifying as Evangelical Christian is declining, the actual numbers of people who identify as Evangelical Christian is growing. The disconnect is in part due to the growth in the religious Nones, who are the fastest growing category and now the second largest category of religion after Evangelical Protestants. The Nones, according to the Pew study, have grown by approximately 19 million people in seven years (America's Changing Religious Landscape 2015). As noted by one of the Pew Researchers, "One of the most important factors in the declining share of Christians and the growth of the 'nones' is generational replacement. As the Millennial generation enters adulthood, its members display much lower levels of religious affiliation including less connection with Christian Churches, than older generations" (America's Changing Religious Landscape 2015). There has been growth within the Nones in the percent who identify as atheist or agnostic (25\% in 2007 to $31 \%$ in 2014). But the report also notes that the growth rate of Nones is higher in whites than other racial/ethnic groups. The narratives around religion are shifting, but those shifts are not only dependent on age or general social attitudes 
in the United States. The U.S. is made up of a multitude of subcultures that interpret and narrate religious experiences differently, which can account for why there is also a racial/ethnic difference in religious affiliation.

In 2014, for example, the United Methodist Church (UMC) was the largest Mainline Protestant group in the United States. But in late February-early March 2019 a vote was held in the General Conference regarding the ordination and marriage of LGBTQIA members of the denomination. Those who opposed the "One Church" proposal in favor of the "Traditional Plan" that strengthened current policies of exclusion narrowly won the vote. While the evidence would indicate that the opposition vote was due heavily to international membership in the UMC, there was strong support of a sub-population of the American UMC who, it would appear, had significant influence on the vote (Steele 2019). The UMC in the United States is now in a state of crisis. United Methodist affiliated Colleges and Universities have increasingly come out against the vote and re-affirmed their values of inclusion, while individual UMC churches are doing the same (Redden 2019). While at this writing it is unclear what will happen, some Colleges and Universities may consider disaffiliating with the UMC and there could be a schism in the denomination itself. That will once again alter the landscape of religion in the United States and is a further example of how social and political issues are deeply tied to theological issues that are continually fracturing religion in the United States. Conflict, it would seem, is growing.

Social and political conservativism has a strong correlation with Evangelical Protestantism, as will be shown in a moment. But the Pew study also noted that there is a growth in the number of Catholics, Orthodox Christians, and Mormons who consider themselves Evangelical or Born Again within their own traditions, a notion that strikes many scholars of religion as an odd pairing of language. What this may indicate is a shifting in narratives where "Evangelical" or "Born Again" reference attitudes about Christianity that transcend denominational lines and point more to social and political attitudes in a larger narrative of what it means to be a true Christian. It is to these narratives, then, that we must turn in order to gain a better understanding of these changes in religion in the United States.

\section{Social, Political, and Theological Narratives of Exclusion}

Two of the clearest examples of the fracturing of religion in the United States are found around the social and political issues of inclusion of immigrants/refugees and LGBTQIA persons. Political and social narratives are often inseparable from the religious narratives. As people identify with a social or political narrative, they will also identify with a religious narrative. As politics and public life in the United States become more contentious around these issues, then, religion will too. Even within the Pew study, researchers noted that while the percentage of the population identifying as Christian or even as overall religious may be shrinking, those who do identify as religious may be becoming more overtly religious and more willing to share their personal brand of religiosity in the public sphere (U.S. Public Becoming Less Religious 2015). There is significant evidence to support this claim, particularly around the political and social voices of Evangelical Christians around these issues.

A Religion Dispatches report describes "Project Blitz" an initiative to generate and promote bills that support a political agenda of the Christian Right.

The bills are seemingly unrelated and range widely in content-from requiring public schools to display the national motto, "In God We Trust" (IGWT); to legalizing discrimination against LGBTQIA people; to religious exemptions regarding women's reproductive health. The model bills, the legislative strategy and the talking points reflect the theocratic vision that's animated a meaningful portion of the Christian Right for some time. In the context of Project Blitz's 116-page playbook, however, they also reveal a sophisticated level of coordination and strategizing that echoes the American Legislative Exchange Council (ALEC), which infamously networks probusiness state legislators, drafts sample legislation, and shares legislative ideas and strategies (Clarkson 2018). 
The political influence of the Christian Right, going back to the Reagan years when Jerry Falwell ${ }^{1}$ claimed to have helped put Reagan into the White House (Flory 2017) and later claims with the election of George W. Bush that God was back in the White House after the Clinton years, has been significant (Borger 2005). The close ties between Evangelical Protestantism, the Republican Party, and populist movements in the United States show a narrative of a holistic world view. To be a true Christian is to view the United States as a Christian Nation, and often more explicitly as a white Christian nation, where things like immigration/refugees and LGBTQIA persons threaten the power and privilege of that identity. To threaten that identity is to, in some sense, stand against the will of God.

What is not clear, and perhaps cannot be made explicitly clear, is if the social and political attitudes are legitimized by or driven by religious narratives. They are inseparable, and perhaps the best way to address the religious shifts in the United States is to address them as a network of the social, political, and theological narratives. In the five years since the last Pew study, many things have changed politically that may make the next Pew study show even greater change. Most importantly, what has changed is the rise and election of Donald Trump as President of the United States. The narrative he is putting forth is not incompatible with previous narratives, but he is emphasizing the divide between a more nativist Christian approach to social, political, and theological diversity and a more progressive engagement with those ideas.

University of Maryland's Critical Issues Poll surveys spanning 2016-2017 display the effect of Trump's nativist populist rhetoric on a range of issues relating to foreign policy. For example, an April 2017 poll shows a deep partisan divide over attitudes toward Muslim refugees, with 88 percent of Republicans supporting a Muslim ban and 86 percent of Democrats opposing one. In another example related to immigration, the survey found that 84 percent of Trump voters support a border wall with Mexico while 87 percent of Clinton voters oppose the wall. Thus, Trump supporters display nativist foreign policy attitudes while non-supporters' attitudes appear in firm opposition (Kane and McColluch 2017).

Even before the rise of President Trump, the link between nativism, Republicanism, and Evangelicalism in the context of a White Christian America were impacting views of immigration. According to a study by Jeremy Rehwaldt of Protestant and Catholic churches in the Midwest,

In the churches I studied, the call to welcome the stranger often butts up against the ideology of Latino threat I described earlier. One person in an adult education class I visited put it this way: "I know that we are to care for the stranger, but immigrants are wasting my tax dollars in the emergency room and the schools. What am I supposed to do?" Moreover, the idea of "welcoming the stranger" has within it the idea that Latino immigrants are "strangers"- they are not like "us". As noted earlier, many of the Protestant congregation members told me they believed that the Latinos in their community would never join their church, that they were "different" in ways that created a disconnection (Rehwaldt 2015).

The narrative of Latin American immigrants as dangerous is a regular refrain of the Trump administration. The narratives pre-date his presidency, but he has made significant use of them and, in turn, certain Evangelical leaders have used his voice to promote these notions and the union of Evangelical Christianity with these political and social narratives. Hate groups, as noted by the Southern Poverty Law Center, are on the rise (Beirich 2019).

Further studies have shown significant defection of Evangelical Christians in particular from the Democratic to the Republican Party related to the issue of immigration/refugees and LGBTQIA persons.

1 It should be noted that the vocabulary is fluid. While Falwell might better be described as Fundamentalist, indicating further distinction from what is referred to as Mainline Protestantism, the definitions are not set. In order to match the language of the Pew study, this essay will use the term Evangelical, acknowledging that there is more diversity of perspective in Evangelical Christianity than the Pew study is able to capture based on how it is using the term. 
As the Democratic Party becomes more ethnically and religiously diverse and even embraces that diversity, people who formerly identified with the Democratic Party are becoming Republican precisely because of those narratives of inclusion (Ehrkamp and Nagel 2012). Some individuals recognize the conflict between theological concerns for the stranger and socio-political fear of outsiders. Yet for many, the socio-political narratives ultimately carry more weight, which will lead to a change in the theological narratives (Rehwaldt 2015).

Given these narratives of exclusion, it is not surprising to find religious life fracturing in the United States. With the growth of non-Christian religions and the increased concerns with the value of immigrants, refugees, LGBTQIA persons, and diversity in general on the part of many Mainline Protestant, Catholic, and even some Evangelical Protestant communities, the narratives of religion in the United States are at a significant crossroads as the conflict becomes a crisis that affects people's lives in very real ways.

\section{Social, Political, and Theological Narratives of Inclusion}

All of this will mean that the counterpoint to narratives of exclusion are the narratives of inclusion, the attempts by individuals and groups to create communities where all feel both welcome and valued. Religious communities can provide a sense of social and even political belonging for immigrant and refugee groups (Rehwaldt 2015). The social belonging can give a voice to political participation that creates an even greater sense of being a part of the whole of American society among non-Christian communities (see for example the Center for American Islamic Relations and the Anti-defamation League among others). Nevertheless, the social and political narratives that allow a sense of belonging when tied to religious communities are also, as we have seen, reasons for their exclusion. They threaten a social order that allows privilege and supremacy to some over others and threaten the identity of many Evangelical Protestants. Looking at this conflict, scholars of religion must ask ourselves if we have a role in the conversation to reshape the conflicting narratives and create a space of reconciliation that brings people together while privileging a sense of pluralism over simple assimilation.

The fractured nature of religious life in the United States is both a danger and an opportunity. While the risk of exclusionary rhetoric becoming performative in acts of hate and violence is real, there is also an opportunity to respond. Returning to the Pew poll, the growth in the Nones is largely among white Millennials, which at least for a while will dominate the political and social landscape as it grows in the religious one. The Nones are seemingly much more open to transcontextual narratives of both inclusion and reconciliation. The second important thing to note from the previous sections is the use of conflicted religious language. There is recognition even by those promoting a narrative of exclusion that inclusion and reconciliation are embedded in the tradition. The frame already exists, as does an opening into the conversation. As scholars of religion step through that opening into the frame, there is real possibility for reshaping the narratives. The transcontextual narrative does not come from the outside but a blending of the threads of people inside a variety of frames in a way that can speak to their needs and their theological concerns.

There are certainly strong Evangelical Protestant voices in the academy that will choose, on extensive theological grounds, the path of exclusion (Moe 2017). However, one frequently also finds a concern from scholars of religion towards the ability of religion to embrace theological diversity in order to create social, political, and religious communities of inclusion. These narratives of religion reframe tradition to create reconciling spaces, and many scholars of religion (as noted by Kurtz in the introduction) see an obligation to address exclusion and call it out as theologically misguided. But the challenge for such scholars is to move out of the academic realm and into the public sphere to actually impact the lives of religious people across the United States. As noted by Penny Edgel, the election of Donald Trump as President of the United States has legitimized certain narratives of exclusion that require scholars of religion to engage in a more directive way than before. But there are challenges to this. She says, 
Mr. Trump did not invent the link between White racial resentment and Whites' economic fears (Anderson 2016); but he did take full advantage of it. He ran a campaign telling his largely White voters that "the establishment" has forgotten them because its elites have been too busy courting the votes of Black and Latino Americans, and too busy worrying about looking good in the eyes of sophisticated Europeans by championing open borders, to care about protecting the jobs of White Americans (Edgell 2017).

The strong tendency in Mainline Protestant, Catholic, and even religious Nones toward narratives of inclusion respond to the dangers exclusive narratives pose to people. The recent declaration by President Trump of a national emergency at the U.S. border with Mexico led the U.S. Congress to vote against that declaration. President Trump was forced to veto that vote in order to get the "National Emergency" status he needed in order to get funding for the border wall. Many religious groups have come out against this declaration. Notable for the affiliation of my own institution is the statement by Sister Patricia McDermott, RSM, President of the Sisters of Mercy of the Americas who said,

Neither the continued government shutdown nor a declaration of national emergency aimed at funding a wall will correct years of failed U.S. immigration policy, or ameliorate the U.S.'s role in the root causes of migration.

Make no mistake, there is a humanitarian crisis on the border, but it is one of the Trump Administration's own making. One where asylum-seekers are forced to wait in dangerous and unhealthy conditions for weeks while their asylum claims are assessed and decided.

Let us be clear: This is not the time to close our borders or build walls. Now is the time to stop the fear mongering and demonstrate our shared humanity in how we respond to our sisters and brothers in Christ (Sisters of Mercy Respond to Oval Office Address 2019).

When comparing this statement in its social, political, and theological implications to the earlier statements, the fracturing of religion in the United States becomes clear. The political and social narratives intertwined with religious narratives make these perspectives incompatible to the point of questioning whether they can all fit under an umbrella of "Christian." The growth in non-Christian religions and religious Nones alongside concerns with immigrants, refugees, and LGBTQIA persons raise serious questions about the work of scholars of religion in addressing this fractured state. When real people are being affected by the ideological narratives, can scholars of religion sit idly by? Changes in the political and social make-up of the United States, for example the increasingly conservative Supreme Court with the addition of Brett Kavanaugh, changes the reality on the ground for the Christian Right and its political aspirations as well as the political hegemony it seeks. But to what end? Is it for the glory of God? Is it for the sake of saving souls? Is it just about winning an argument and controlling the country by controlling the demographics and the hearts and minds of the people? These are difficult if not impossible questions to answer. But the questions must still be asked and addressed.

If the fracturing of religion and the potentially broken state of it in the United States today can be interpreted as the difference between protecting privilege and supporting inclusion (which is one potential interpretation of the situation), do scholars of religion dare to call out religious voices and narratives as broken? If the changing demographics are happening and cannot be stopped, which the Pew polls seem to suggest is the case, then the alienating narratives of exclusion cannot be left unaddressed. Religious narratives that cannot respond constructively to the social and political environments in which people live cannot survive. If scholars get involved, they cannot claim to be "unbiased" even though their bias may be based on good evidence. Then one must ask how it is possible for scholars to reach the people in religious communities, either in terms of support or in attempts to reshape potentially dangerous religious narratives. It is, therefore, with the framing of religious narratives that scholars of religion can enter the conversation and respond to the changing religious landscape of the United States in constructive and affirming ways. Reconciliation is needed 
that recognizes and values diversity. Narratives that transcend particular contexts by creating liminal and mediating spaces may have the ability to respond to the always changing religious landscape that does not deny the value of diversity but instead reconciles with it in order to create communities of inclusion.

\section{Conclusions}

Returning to the description of performative narrative, it seems that to reach the level of reconciliation and inclusion requires the narratives to inhabit the same social structures as the narratives of exclusion. Doing so can provide the foundations for such reconciliation because our narratives exists within larger narratives. These letters were written and edited up to the last minute in order to engage each other and the constantly evolving situation of the President's narrative and the resurgence of long suppressed narratives of exclusion. They inhabit the same social space. They are performative of reconciliation in that they speak with each other. They build a community across a wide array of individuals by engaging each other's letters and by the powerful quality of speaking as if there were one voice. The letters are available online and being used by church groups and schools to start or enhance conversations of reconciliation and inclusion. Imagination allows communal narratives to fill gaps, to build connections. I am reminded of the description in Jurassic Park of the reviving of the dinosaurs from extinction. DNA was extracted, but the strands were incomplete. Where they were missing pieces, frog DNA was put in to fill the gaps. Narrative imagination is like this. It is the ability to insert the connections into the broken strands of the story, to move from exclusion to reconciliation in a way that creates inclusion and diversity rather than fearing it.

Funding: This research received no external funding.

Acknowledgments: The author would like to acknowledge the assistance of students in the Evolving Religion class: Katelin Snable, Christian Copper, Vincent Marrazzo, Ella DiPietro, Grace Petron, and Harris Williams.

Conflicts of Interest: The author declares no conflict of interest.

\section{References}

America's Changing Religious Landscape. 2015. Pew Forum. Available online: http://www.pewforum.org/2015/ 05/12/americas-changing-religious-landscape/ (accessed on 15 March 2019).

American Values Religious Voices. 2017. Available online: http://www.valuesandvoices.com/the-campaign/ (accessed on 15 March 2019).

Beirich, Heidi. 2019. Rage against Change: White Supremacy Flourishes amid Fears of Immigration and Nation's Shifting Demographics. Intelligence Report 166: 35-42.

Borger, Julian. 2005. How Born-Again George Became a Man on a Mission. The Guardian. Available online: https://www.theguardian.com/world/2005/oct/07/usa.georgebush (accessed on 15 March 2019).

Cavanaugh, William T. 2007. Does Religion Cause Violence? Behind the Common Question Lies a Morass of Unclear Thinking. Harvard Divinity Bulletin 35: 3. Available online: https://bulletin.hds.harvard.edu/articles/ springsummer2007/does-religion-cause-violence (accessed on 15 March 2019).

Clarkson, Frederick. 2018. "Project Blitz" Seeks to Do for Christian Nationalism What ALEC Does for Big Business. Religion Dispatches. Available online: http://religiondispatches.org/project-blitz-seeks-to-do-for-christiannationalism-what-alec-does-for-big-business/ (accessed on 15 March 2019).

Edgell, Penny. 2017. An Agenda for Research on American Religion in Light of the 2016 Election. Sociology of Religion: A Quarterly Review 78: 1-8. [CrossRef]

Ehret, Verna. 2014. Utopia and Narrative: Theology between the Boundaries of Overhumanization and Hypertheism. In Hope and the Longing for Utopia: Futures and Illusions in Theology and Narrative. Edited by Daniel Boscaljon. Cambridge: Wipf and Stock Publishers.

Ehrkamp, Patricia, and Caroline Nagel. 2012. Immigration, Places of Worship and the Politics of Citizenship in the US South. Royal Geographical Society 37: 624-38. [CrossRef] 
Flory, Richard. 2017. Revisiting the Legacy of Jerry Falwell Sr. in Trump's America. The Conversation. Available online: http://theconversation.com/revisiting-the-legacy-of-jerry-falwell-sr-in-trumps-america79551 (accessed on 15 March 2019).

Itkowitz, Colby, and John Wagner. 2019. Trump Says He Has No Regrets about Sharing Ilhan Omar Video. The Washington Post. Available online: https://www.washingtonpost.com/politics/trump-no-regrets-aboutsharing-ilhan-omar-video/2019/04/16/71070d7c-6044-11e9-bfad-36a7eb36cb60_story.html?utm_term= .7747af3a9122 (accessed on 18 April 2019).

Kane, Catherine, and Caitlin McColluch. 2017. Populism and Foreign Policy: Deepening Divisions and Decreasing Efficiency. Global Politics Review 3: 43.

Kim, Uriah Y. 2017. Letter 6. American Values Religious Voices. Available online: http://www.valuesandvoices.com/ letter6/ (accessed on 15 March 2019).

Klemm, David, and William Schweiker. 2008. Religion and the Human Future: An Essay on Theological Humanism. Oxford: Wiley-Blackwell.

Kurtz, Lester. 2015. Gods in the Global Village: The World's Religions in Sociological Perspective, 4th ed. Thousand Oaks: Sage Publications.

Moe, David Thang. 2017. A Trinitarian Theology of Religions: Themes and Issues in Evangelical Approaches. ERT 41: 234-53.

Pew Forum. 2014. Religious Landscape Survey. Available online: www.pewforum.org/religious-landscape-study/ (accessed on 15 March 2019).

Plaskow, Judith. 2017. Letter 44. American Values Religious Voices. Available online: http://www.valuesandvoices. com/letter44/ (accessed on 15 March 2019).

Presser, Lois. 2016. Criminology and the narrative turn. Crime Media Culture 12: 137-51. [CrossRef]

Redden, Elizabeth. 2019. Dilemma for Methodist Colleges. Inside Higher Ed. Available online: $\quad$ https://www.insidehighered.com/news/2019/03/11/methodist-colleges-and-seminariesreact-church-vote-strengthening-prohibitions-gay?fbclid=IwAR3tgqx4w2h6cBvokg9SfulUy8QZTkIt9f9WUSDHms5BlsUqvWjX6XzFrM\#.XInLMMFHknO.facebook (accessed on 15 March 2019).

Rehwaldt, Jeremy. 2015. Responses by White Christians to Recent Latino Immigration in the Rural U.S. Midwest. Religions 6: 686-711. [CrossRef]

Ricoeur, Paul. 1995. Toward a Narrative Theology: Its Necessity, Its Resources, Its Difficulties. In Figuring the Sacred. Minneapolis: Fortress Press.

Roll, Nick. 2017. 2 More Campus Speakers Shouted Down. Inside Higher Ed. Available online: https://www. insidehighered.com/news/2017/10/12/speaker-protests-continue-options-punishments-unclear (accessed on 15 March 2019).

Rosenberg, Eli. 2019. Poster linking Rep. Ilhan Omar to 9/11 Sparks Outrage, Injuries in W.Va. State Capitol. The Washington Post. Available online: https://www.washingtonpost.com/politics/2019/03/02/posterlinking-rep-ilhan-omar-sparks-outrage-injuries-wva-state-capitol/?utm_term=.af05c443dd4a (accessed on 15 March 2019).

Schleifer, Theodore. 2017. King Doubles Down on Controversial 'Babies' Tweet. CNN Politics. Available online: https://www.cnn.com/2017/03/13/politics/steve-king-babies-tweet-cnntv/index.html (accessed on 18 April 2019).

Sisters of Mercy Respond to Oval Office Address. 2019. Available online: https://www.sistersofmercy.org/aboutus/news-and-events/sisters-of-mercy-respond-to-oval-office-address/ (accessed on 9 January 2019).

Steele, Jeremy. 2019. United Methodists Vote to Keep Traditional Marriage Stance. Christianity Today. Available online: https://www.christianitytoday.com/news/2019/february/united-methodist-lgbt-vote-conference-plan. html (accessed on 15 March 2019).

Stumm, Bettina. 2014. Witnessing Others in Narrative Collaboration: Ethical Responsibility beyond Recognition. Biography 37: 762-83. [CrossRef]

U.S. Public Becoming Less Religious. 2015. Pew Forum. Available online: www.pewforum.org/2015/11/03/u-spublic-becoming-less-religious/ (accessed on 15 March 2019).

(C) 2019 by the author. Licensee MDPI, Basel, Switzerland. This article is an open access article distributed under the terms and conditions of the Creative Commons Attribution (CC BY) license (http://creativecommons.org/licenses/by/4.0/). 